Eur. J. Clin. Chem. Clin. Biochem.

Vol. 32, 1994, pp. 465-472

(c) 1994 Walter de Gruyter \& Co.

Berlin - New York

\title{
Inter-Laboratory External Quality Assessment Schemes for Specific IgE Antibodies The Results of a European Scheme for 1992
}

\author{
By R. Fifield ${ }^{1}$, J.-C. Libeer ${ }^{2}$ and A. P. M. Schellekens ${ }^{3}$ \\ 1 Supra Regional Protein Reference Unit, Cardiff Royal Infirmary, Cardiff, Wales, UK \\ 2 Institut of Hygiene and Epidemiology, Clinical Pathology Department Brussels, Belgium \\ 3 Department of Clinical Chemistry, Catharina-Ziekenhuis, Eindhoven, The Netherlands
}

(Received December 15, 1993/March 11, 1994)

Summary: External quality assessment programmes for specific IgE have been organised for some years in the United Kingdom, Belgium and the Netherlands but independently. This paper describes a co-operation scheme whereby the same samples were circulated simultaneously from each of the three countries and subsequent results combined to produce a single "EURO EQAS" report.

Serum pools were prepared each containing antibodies, at differing concentrations, to 4 different allergens. The allergens surveyed represented the 10 most commonly encountered in Northern Europe.

Results were submitted in grades (or classes) and in quantitative units and they showed some similarity by grade regardless of method used but differed greatly in units probably due to method differences.

This paper shows how results could be treated to produce statistical data for the participants to help them be aware of their performance internally and also in comparison to other users.

\section{Introduction}

In 1967, IgE was defined as a fifth distinct human immunoglobulin and it was shown to be the reaginic antibody $(1,2)$ : Shortly thereafter, serological assays were developed to quantify the total level of IgE and to detect the presence of allergen-specific IgE antibodies in serum (3). Today, diagnostic laboratories throughout the world analyse sera from individuals suspected of having atopic disease using a spectrum of immunochemical reagents and a variety of isotopic and non-isotopic immunoassays $(4,5)$. The commercially available immunoassays for total serum IgE have reached a high level of agreement between methods and laboratories according to past quality assurance schemes: this is primarily due to the availability of well characterised anti-human IgE reagents, internationally recognised human IgE reference preparations and widely used external quality assess- ment schemes. The good inter-assay and inter-laboratory agreement of total serum IgE measurements indicates that this measurement does not present a major technical challenge to regulated diagnostic allergy laboratories and therefore discussion of quality assurance schemes for this analyte will be excluded in this paper. Rather, the emphasis of this overview will be on quality assurance schemes that evaluate the results from laboratories that perform allergen specific IgE antibody measurements using a variety of serological immunoassays. The goal of this report is to describe the results produced by laboratories in the United Kingdom, Belgium and the Netherlands where a co-operative EURO EQAS is currently in operation. Problems associated with the arbitrary nature of IgE antibody assay reporting methods that ultimately prevent effective inter-assay comparisons will be highlighted. The programme will be examined within the context of representative results generated by 
participants of the surveys during the 1992 cycle of distributions.

\section{Allergen-Specific IgE Immunoassay Methods}

Commercially available allergen specific IgE antibody immunoassays are in a state of constant transition as a result of continual improvements in reagent quality, assay design and automated instrumentation. The earliest semi-quantitative non-competitive binding solid phase immunoradiometric assay for IgE antibody was a procedure called the radioallergosorbent test or RAST. Second generation assays have been providing laboratories with less labour-intensive procedures that are more automated, non-isotopic and that use microprocessor-driven instruments. Despite the changes in reagents and instrumentation the majority of available commercial allergen-specific $\operatorname{IgE}$ assays are considered highly complex assays that require skilled technical staff.

IgE antibody immunoassays may be viewed simplistically as being composed of two major attributes. The first and generally less problematic characteristic of $\operatorname{IgE}$ antibody assays is their ability to detect nanogram quantities of IgE, often in the presence of microgram quantities of other immunoglobulins (e.g. IgG) and while this has posed a substantial challenge the analytical sensitivity of most immunoassays today are able to cope with this problem. The second and more variable characteristic of these assays relates to the allergen specificity of the antibody detected in the assay as humans can exhibit immediate-type hypersensitivity to over 300 naturally occurring substances that are extractable from the pollens of trees, grasses and weeds and components released from animals, moulds, insects and foods.

The same crude allergen-containing raw material can be processed differently by two manufacturers, yielding allergen-containing assay reagents that vary widely in their allergenic potency and specificity. The allergen component of the assay must therefore be considered that reagent that produces the greatest variability in IgE antibody measurements obtained with different commercially available methods.

The overall performance of a particular laboratory in the external quality assurance schemes discussed subsequently depends on multiple inter-related variables. Besides the quality of the immunoassay (reagents and procedures) themselves, other important variables include the technical capability of the staff, internal quality control procedures and uncontrolled random errors that can occur during the analysis. If a laboratory is out of control or it produces $\mathrm{IgE}$ antibody results that do not agree with those produced by other laboratories using the same method, then the assay and these other associated variables need to be examined to identify the problem.

\section{Aims of the Euro EQAS for Allergen Specific IgE Antibody Assays}

The aims of the external quality assessment schemes in each of the three countries were similar but it was felt that a co-operative scheme could have many advantages. It was hoped to involve a maximal number of laboratories that are performing specific IgE immunoassays regardless of the size of the laboratory or their method in use. Also the improved size of the database would help useful analysis of data for those laboratories using the less popular commercial methods. As of 1992 the EuroEQAS had 221 participants growing to 239 by the end of the year (the number of participants and the methods in use can be seen in table 1).

This scheme collates qualitative "grade or class" and semiquantitative "unit" measurements that reflect the presence and relative amount of IgE antibody in a particular serum specimen. Differences in the results produced by a single laboratory can be compared to a "group mean" produced by participants using the same method. In this scheme differences in specific IgE antibody results
Tab. 1 Methods in use and number of users of each method.

\begin{tabular}{|c|c|c|c|c|c|c|}
\hline \multirow[t]{3}{*}{ Method } & \multicolumn{2}{|c|}{$\begin{array}{l}\text { United } \\
\text { Kingdom }\end{array}$} & \multicolumn{2}{|c|}{ Belgium } & \multicolumn{2}{|c|}{$\begin{array}{l}\text { Nether- } \\
\text { lands }\end{array}$} \\
\hline & \multicolumn{6}{|c|}{ Distribution number } \\
\hline & 6 & 13 & 6 & 13 & 6 & 13 \\
\hline Pharmacia CAP & 22 & 26 & 45 & 45 & 37 & 43 \\
\hline Pharmacia RAST & 33 & 31 & 16 & 16 & 11 & 12 \\
\hline DPC Alastat & 6 & 7 & 0 & 0 & 9 & 11 \\
\hline Whittaker 3M & 4 & 4 & 0 & 0 & 0 & 0 \\
\hline Kallestad & 1 & 1 & 2 & 2 & 0 & 0 \\
\hline Bioline & 0 & 0 & 6 & 6 & 0 & 0 \\
\hline Ventrex & 0 & 0 & 5 & 5 & 0. & 0 \\
\hline Fooke & 1 & 1 & 0 & 0 & 0 & 0 \\
\hline Ultra & 0 & 0 & 1 & 1 & 0 & 0 \\
\hline Others & 1 & 2 & 11 & 11 & 5 & 6 \\
\hline Total & 68 & 72 & 86 & 86 & 62 & 72 \\
\hline
\end{tabular}

for a particular method are examined between countries and within a laboratory by analysis of the same specimen up to 4 times within a year. The ultimate goal of this scheme is to promote agreement or unanimity of group results such that the majority of laboratories performing a particular allergen specificity/assay combination agree that a specimen either does or does not contain specific IgE antibody (and also if possible agree on the relative "concentration" of a particular IgE antibody). The quality assessment attempts to use the information to identify problem assays and laboratories and remains flexible in order to modify the scheme design in order to improve both inter-method and inter-laboratory standardisation.

In all specific IgE antibody assays a class 0 is defined as the absence of specific IgE antibody in the serum whilst classes 1 through 6 show increasing concentrations of the specific $\operatorname{IgE}$ antibody and they have been shown to be associated with increasing clinical sensitivity to the allergen in question.

In this quality assurance scheme it has been difficult to evaluate laboratory performance with IgE antibody results in class data except in a gross manner. Borderline results are difficult to interpret except when the serum specimen is known to have no IgE antibody to that allergen specificity. Information about the performance of the laboratory and the assay method that it uses in detecting a spectrum of low to high levels in IgE antibody positive specimens can be lost when the scheme uses only class scoring analysis. Most IgE antibody assays also provide a more quantitative unitage assignment of $\operatorname{IgE}$ antibody which is based on total serum IgE or an allergen specific antibody reference curve that has been constructed with a calibration serum assigned an arbitrary number of "units". IgE antibody levels in test specimens can then be reported in the same "units" interpolated from this reference curve. At present the quantitative relationship between the arbitrary units used by the various commercial assays is not known. Thus, comparisons of the levels of $\operatorname{IgE}$ antibody reported by the participants in units using a variety of commercial methods can be viewed only within a method group and not between method groups.

\section{Survey Design and Sample Specifications}

Four serum pools containing prescribed specific $\operatorname{lgE}$ antibodies were prepared at the serum bank of Pharmacia (Uppsala, Sweden) and each pool contained specific antibodies to four different allergens at varying concentration levéls. In addition each pool was 
ascribed a "negative allergen" one which the pool was known not to contain (see tab. 2).

Three samples were distributed every 6 weeks by the national scheme organisers and the participants were asked to test against three named allergens in each sample and participants had to report their results within 5 weeks. This randomised sampling enabled the identity of each pool to be kept secret from the participants on receipt of their samples.

Over the period of 1992 eight distributions were undertaken and each pool was circllated on 6 occasions and each allergen in each pool was tested either 3 or 4 times.

Results from each participant were sent in the first instance to their national organiser who issued national reports only within their country and then all results were sent to the EURO organiser who is based in the UK and then a EURO report was issued to all participants.

The allergens chosen for analysis represented a cross-section of the 10 or so most common allergens in Western Europe and the most common allergens were represented in more than one serum pool at varying concentrations of IgE antibody level. The scheme was anonymous in that each participant was identified by a number with no organiser knowing the identity of all the participants in the scheme.

\section{Data Analysis and Calculations}

Results were analysed by sample number and by individual allergens within a sample. As mentioned earlier results were analysed by class or grade and by units and divided by method.

Results by grade were analysed as an overall group and then by method so that participants could see these results as the number - of participants reporting each grade as a group and also by method.

Results in units were analysed using the variance index scoring system (described fully by Bullock \& Wilde (6)) using the group laboratory trimmed mean as the designated value for each allergenspecific antibody.

For each allergen-specific antibody a bias index score is calculated for each laboratory and this is used to calculate the mean running variance index score for each allergen specific antibody and overall mean running index score which represents an overall performance

Tab. 2 Serum pools (SP) in circulation in 1992.

\begin{tabular}{|c|c|c|c|}
\hline Serum pool & Allergen & Level & \\
\hline SP01 & $\begin{array}{l}\text { D1 } \\
\text { F1 } \\
\text { T3 } \\
\text { G5 }\end{array}$ & $\begin{array}{l}\text { Low } \\
\text { Medium } \\
\text { High } \\
\text { High }\end{array}$ & M3 negative \\
\hline SP02 & $\begin{array}{l}\text { D1 } \\
\text { E1 } \\
\text { M3 } \\
\text { F3 }\end{array}$ & $\begin{array}{l}\text { High } \\
\text { Medium } \\
\text { Low } \\
\text { Medium }\end{array}$ & T3 negative \\
\hline SP03 & $\begin{array}{l}\text { D1 } \\
\text { E5 } \\
\text { G6 } \\
\text { T3 }\end{array}$ & $\begin{array}{l}\text { Medium } \\
\text { Low } \\
\text { High } \\
\text { medium }\end{array}$ & F1 negative \\
\hline SP04 & $\begin{array}{l}\text { D1 } \\
\text { E1 } \\
\text { M6 } \\
\text { F13 }\end{array}$ & $\begin{array}{l}\text { Low } \\
\text { High } \\
\text { Medium } \\
\text { Medium }\end{array}$ & F2 negative \\
\hline
\end{tabular}

criteria for each laboratory (for a complete explanation of data analysis and statistical calculation see tab. 3).

\section{Results}

\section{(a) By grades}

The results in grades for each allergen-specific antibody in each of the 4 pools circulated are shown in table 4 and they show that in the majority of cases almost all the laboratories were able to identify those allergens present and those absent in the 4 serum pools. The Pharmacia CAP method in the main reported higher grades to each allergen compared to the Pharmacia RAST and other methods in use but in some of the allergens a low concentration of antibody did result in some methods

Tab. 3 Variance index scoring system.

The variance index scoring system gives a simple but reliable indication of laboratory performance which has proved robust over many years of use. The system depends on a number of related indices which are defined as follows:

Variance index (VI): The difference, irrespective of sign, between the result returned and the designated value (DV), expressed as a percentage of the designated value, divided by the chosen coefficient of variation (CCV) for the analyte expressed as a percentage.

$$
\mathrm{VI}=\frac{(\mathrm{x}-\mathrm{DV})}{\mathrm{DV}} \cdot \frac{10000}{\mathrm{CCV}}
$$

Variance index score: For values of variance index less than 400 , variance index score $=$ variance index. The maximum variance index is 400 , for all values of variance index greater than 400 , variance index score $=400$.

Mean running variance index score: The mean of the variance index scores in the current analytical time window (for most analytes this will be the last 4 results).

Bias index score: Identical to the variance index score but retaining the sign; a result higher than the designated value will give a positive bias index score, whilst a lower result will give a negative bias index score.

Mean running bias index score: The arithmetic mean of the bias index scores in the current analytical time window.

Standard deviation of the bias index score: The standard deviation (SD) of the bias index scores in the current analytical time window.

Designated value: For this scheme and analytes this is the method laboratory trimmed mean.

All laboratory trimmed mean: The recalculated mean value after exclusion of all results outside 3 SD from the all trimmed laboratory mean. In this scheme the trimming is performed at the 7.5th and 92.5 th centiles.

Chosen coefficients of variation: A scaling factor for each analyte to correct for the current state of the art so as to produce variance index scores in a "common currency". The chosen coefficient of variation does not represent a "clinically acceptable error".

Overall mean running variance index score: The mean of the 24 most recent variance index scores irrespective of analyte for each laboratory (minimum of 12 results required for calculation). 
Tab. 4 Results in grades by scrum pool (SP) and allergen.

\begin{tabular}{lllllllllll}
\hline Allergen & $\begin{array}{l}\text { Distrib- } \\
\text { ution } \\
\text { no. }\end{array}$ & $\mathrm{n}$ & 0 & 1 & 2 & 3 & 4 & 5 & 6 \\
\hline
\end{tabular}

Serum pool SP01

\begin{tabular}{|c|c|c|c|c|c|c|c|}
\hline $\begin{array}{r}6 \\
7 \\
9 \\
13\end{array}$ & $\begin{array}{l}201 \\
189 \\
176 \\
169\end{array}$ & $\begin{array}{l}48 \\
33 \\
23 \\
13\end{array}$ & $\begin{array}{l}35 \\
36 \\
36 \\
37\end{array}$ & $\begin{array}{l}114 \\
109 \\
101 \\
103\end{array}$ & $\begin{array}{r}4 \\
11 \\
14 \\
16\end{array}$ & $\begin{array}{l}0 \\
0 \\
1 \\
0\end{array}$ & $\begin{array}{l}0 \\
0 \\
1 \\
0\end{array}$ \\
\hline $\begin{array}{r}6 \\
9 \\
9 \\
13\end{array}$ & $\begin{array}{l}194 \\
181 \\
162 \\
168\end{array}$ & $\begin{array}{l}2 \\
0 \\
1 \\
4\end{array}$ & $\begin{array}{l}0 \\
0 \\
0 \\
1\end{array}$ & $\begin{array}{l}18 \\
16 \\
11 \\
13\end{array}$ & $\begin{array}{l}156 \\
151 \\
140 \\
138\end{array}$ & $\begin{array}{r}16 \\
13 \\
9 \\
12\end{array}$ & $\begin{array}{l}2 \\
1 \\
1 \\
0\end{array}$ \\
\hline $\begin{array}{r}6 \\
9 \\
11\end{array}$ & $\begin{array}{l}153 \\
137 \\
126\end{array}$ & $\begin{array}{l}0 \\
0 \\
1\end{array}$ & $\begin{array}{l}0 \\
0 \\
0\end{array}$ & $\begin{array}{l}9 \\
6 \\
7\end{array}$ & $\begin{array}{l}58 \\
49 \\
35\end{array}$ & $\begin{array}{l}84 \\
80 \\
80\end{array}$ & $\begin{array}{l}1 \\
2 \\
3\end{array}$ \\
\hline $\begin{array}{r}7 \\
9 \\
11 \\
13\end{array}$ & $\begin{array}{l}125 \\
103 \\
105 \\
123\end{array}$ & $\begin{array}{l}1 \\
0 \\
0 \\
0\end{array}$ & $\begin{array}{l}1 \\
0 \\
0 \\
0\end{array}$ & $\begin{array}{l}2 \\
0 \\
1 \\
1\end{array}$ & $\begin{array}{l}20 \\
14 \\
10 \\
11\end{array}$ & $\begin{array}{l}46 \\
49 \\
49 \\
64\end{array}$ & $\begin{array}{l}52 \\
39 \\
44 \\
44\end{array}$ \\
\hline $\begin{array}{r}? \\
9 \\
11\end{array}$ & $\begin{array}{l}141 \\
156 \\
127\end{array}$ & $\begin{array}{r}110 \\
123 \\
80\end{array}$ & $\begin{array}{l}24 \\
26 \\
42\end{array}$ & $\begin{array}{l}4 \\
6 \\
5\end{array}$ & $\begin{array}{l}2 \\
1 \\
0\end{array}$ & $\begin{array}{l}1 \\
0 \\
0\end{array}$ & $\begin{array}{l}0 \\
0 \\
0\end{array}$ \\
\hline
\end{tabular}

Serum pool SP02

\begin{tabular}{rrrrrrrrrr} 
E1 & 6 & 197 & 0 & 0 & 220 & 173 & 4 & 0 & 0 \\
& 10 & 182 & 3 & 2 & 25 & 144 & 8 & 0 & 0 \\
& 11 & 171 & 3 & & 22 & 137 & 7 & 0 & 0 \\
M3 & 6 & 156 & 12 & 12 & 78 & 54 & 0 & 0 & 0 \\
& 10 & 143 & 19 & 14 & 56 & 53 & 0 & 1 & 0 \\
& 12 & 144 & 14 & 20 & 64 & 43 & 3 & 0 & 0 \\
& 13 & 131 & 17 & 17 & 52 & 45 & 0 & 0 & 0 \\
F3 & 6 & 163 & 2 & 2 & 42 & 112 & 5 & 0 & 0 \\
& 8 & 138 & 1 & 3 & 37 & 94 & 3 & 0 & 0 \\
& 11 & 134 & 2 & 5 & 35 & 87 & 5 & 0 & 0 \\
& & & & & & & & \\
& & & & & & & & & \\
& & 175 & 0 & 0 & 4 & 69 & 102 & 0 & 0 \\
& 10 & 184 & 0 & 1 & 5 & 68 & 109 & 1 & 0 \\
& 12 & 185 & 0 & 2 & 3 & 74 & 104 & 2 & 0 \\
& 13 & 167 & 1 & 2 & 6 & 50 & 107 & 1 & 0 \\
T3 & 8 & 70 & 52 & 14 & 3 & 1 & 0 & 0 & 0 \\
& 11 & 117 & 79 & 29 & 8 & 1 & 0 & 0 & 0 \\
& 12 & 130 & 88 & 29 & 13 & 0 & 0 & 0 & 0 \\
& 13 & 124 & 86 & 25 & 13 & 0 & 0 & 0 & 0 \\
\hline
\end{tabular}

reporting a grade 0 or 1 whilst other methods reported a grade 2 or higher.

A point showing a difference of allergen recognition was shown in the results to "house dust mite" present in pools SP01 and SP04 where Pharmacia CAP users report positive grades in both pools but DPC users report positive grades in pool SP01 but negative grades in pool SP04 (tab. 5).

(b) By units

A particular laboratories performance can in theory be more rigorously evaluated with unit results interpolated
Tab. 4 Continued.

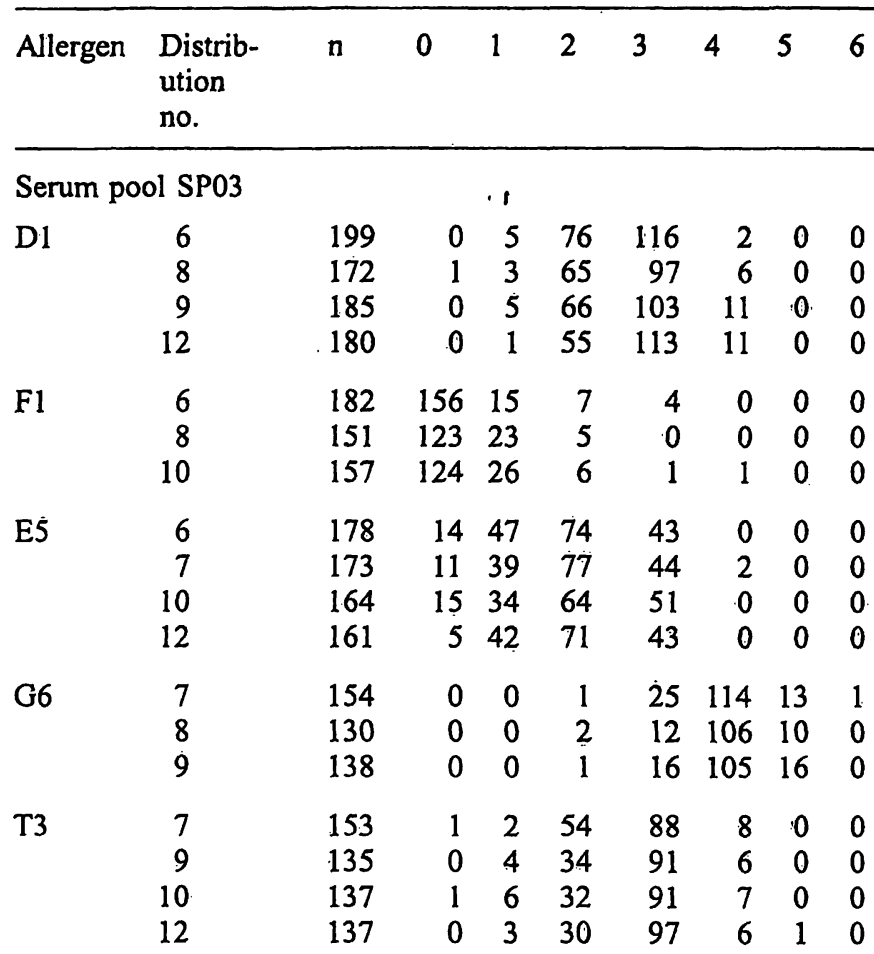

Serum pool SP04

\begin{tabular}{|c|c|c|c|c|c|c|c|c|}
\hline $\mathrm{El}$ & $\begin{array}{r}7 \\
8 \\
12 \\
13\end{array}$ & $\begin{array}{l}195 \\
168 \\
181 \\
169\end{array}$ & $\begin{array}{l}1 \\
1 \\
0 \\
2\end{array}$ & $\begin{array}{l}0 \\
0 \\
0 \\
1\end{array}$ & $\begin{array}{l}4 \\
6 \\
4 \\
5\end{array}$ & $\begin{array}{l}82 \\
65 \\
68 \\
52\end{array}$ & $\begin{array}{r}102 \\
95 \\
106 \\
107\end{array}$ & $\begin{array}{l}4 \\
1 \\
3 \\
2\end{array}$ \\
\hline M6 & $\begin{array}{r}7 \\
10 \\
12\end{array}$ & $\begin{array}{r}113 \\
101 \\
99\end{array}$ & $\begin{array}{l}0 \\
1 \\
1\end{array}$ & $\begin{array}{l}5 \\
5 \\
2\end{array}$ & $\begin{array}{l}31 \\
29 \\
29\end{array}$ & $\begin{array}{l}73 \\
62 \\
64\end{array}$ & $\begin{array}{l}4 \\
4 \\
3\end{array}$ & $\begin{array}{l}0 \\
0 \\
0\end{array}$ \\
\hline $\mathrm{F} 13$ & $\begin{array}{r}7 \\
11 \\
12\end{array}$ & $\begin{array}{l}140 \\
121 \\
130\end{array}$ & $\begin{array}{l}0 \\
1 \\
3\end{array}$ & $\begin{array}{l}3 \\
3 \\
0\end{array}$ & $\begin{array}{l}36 \\
25 \\
30\end{array}$ & $\begin{array}{l}96 \\
86 \\
92\end{array}$ & $\begin{array}{l}5 \\
6 \\
5\end{array}$ & $\begin{array}{l}0 \\
0 \\
0\end{array}$ \\
\hline D1 & $\begin{array}{r}8 \\
10 \\
11 \\
13\end{array}$ & $\begin{array}{l}168 \\
179 \\
168 \\
169\end{array}$ & $\begin{array}{l}19 \\
21 \\
22 \\
16\end{array}$ & $\begin{array}{l}32 \\
29 \\
20 \\
22\end{array}$ & $\begin{array}{l}110 \\
118 \\
117 \\
125\end{array}$ & $\begin{array}{l}7 \\
8 \\
9 \\
4\end{array}$ & $\begin{array}{l}0 \\
3 \\
0 \\
2\end{array}$ & $\begin{array}{l}0 \\
0 \\
0 \\
0\end{array}$ \\
\hline $\mathrm{F} 2$ & $\begin{array}{r}8 \\
10 \\
11 \\
13\end{array}$ & $\begin{array}{l}145 \\
157 \\
152 \\
151\end{array}$ & $\begin{array}{l}127 \\
139 \\
134 \\
135\end{array}$ & $\begin{array}{l}14 \\
14 \\
11 \\
12\end{array}$ & $\begin{array}{l}3 \\
4 \\
4 \\
4\end{array}$ & $\begin{array}{l}0 \\
0 \\
3 \\
0\end{array}$ & $\begin{array}{l}1 \\
0 \\
0 \\
0\end{array}$ & $\begin{array}{l}0 \\
0 \\
0 \\
0\end{array}$ \\
\hline
\end{tabular}

from a reference curve than with qualitative grade score results but at present there are no internationally recognised IgE antibody standards that have been calibrated for any allergen specificity. It is therefore not possible to determine a "true value" for any serum specimen and to permit the assessment of analytical sensitivities of the various assays.

Therefore at the present time we are limited to an assessment of a laboratories performance using a comparison of results by those laboratories using the same method and hence a designated value of the "method mean" is used for each method. Despite the great variation in re- 
Tab. 5 Results in grades to D1 in two serum pools by method and for two distribution numbers.

\begin{tabular}{lllllll}
\hline Method & $\mathrm{n}$ & 0 & 1 & 2 & 3 & 4 \\
\hline
\end{tabular}

a) Serum pool SP01; distribution no. 6

\begin{tabular}{lrrrrrr}
\hline All & 201 & 48 & 35 & 114 & 4 & 0 \\
Bioline & 3 & 3 & 0 & 0 & 0 & 0 \\
DPC & 13 & 0 & 2 & 9 & 2 & 0 \\
Others & 15 & 10 & 2 & 3 & 0 & 0 \\
CAP & 98 & 2 & 0 & 94 & 2 & 0 \\
RAST & 58 & 29 & 27 & 2 & 0 & 0 \\
Ventrex & 4 & 1 & 2 & 1 & 0 & 0 \\
\hline
\end{tabular}

b) Serum pool SP04; distribution no. 13

\begin{tabular}{lrrrrrr}
\hline All & 169 & 16 & 125 & 125 & 4 & 2 \\
Bioline & 3 & 3 & 0 & 0 & 0 & 0 \\
DPC & 10 & 2 & 5 & 2 & 1 & 0 \\
Others & 11 & 5 & 4 & 2 & 0 & 0 \\
CAP & 88 & 2 & 0 & 82 & 3 & 1 \\
RAST & 43 & 1 & 6 & 36 & 0 & 0
\end{tabular}

sults between methods the stability of the all laboratory trimmed mean for every allergen demonstrated the stability of the pools over the period of distributions. Within each method the Pharmacia CAP system exhibited the lowest coefficients of variation (CV) for any allergen compared to the other methods; this may be due in some part to this method having the greatest number of users or it being the most precise method?

Although the numerical results for each method vary it was hoped that a comparison could be done using a weighting factor but is was then obvious that the dose responses between allergen specificities differed between methods. This problem can be shown by comparing the ratio of results using method mean values for the different allergen specificities expressed as a ratio of two methods (see tab. 6).

Results in units varied greatly between the methods in use, so the all laboratory trimmed mean was not used to evaluate performance criteria and also because of the differences in results between allergens it was necessary to assess laboratory performance by allergen. Therefore the variance index scoring system was to be used based on a designated value for each method, for results to each allergen in each serum pool. A mean running variance index score was calculated for each allergen specificity for each laboratory based on the last 4 results a laboratory returned to that allergen - hence it portrayed a "moving window" performance. A classification of performance based on arbitrary separation of mean running variance index scores was established as follows:

\begin{tabular}{lc}
\hline Class of performance & Mean running variance index score \\
\hline Good & $<100$ \\
Average & $100-200$ \\
Acceptable & $201-300$ \\
Unacceptable & $>300$ \\
\hline
\end{tabular}

Table 7 shows mean running variance index scores divided into the above categories and by country for all the allergen specificities circulated during 1992.

With a chosen coefficient of variation of $15 \%$ for allergen specificities it was heartening to see the majority of laboratories with mean running variance index scores of $<200$ for all allergens. As a measure of overall analytical performance overall mean running variance index score was used with a "moving window" of the last 24 results regardless of allergen specificity and again as with mean running variance index score it was decided to classify performance in just the same way and table 8 shows the number of laboratories in each classification and then divided by country. More than $70 \%$ of participants had overall mean running variance index scores of $<200$ with little difference by country: with this method of "scoring" only being started in 1992 it is a little early yet to see if participants are showing improvements in overall performance.

\section{Discussion}

Although EQA schemes for specific IgE have been organised in each of the three participating countries (UK, Belgium and the Netherlands) for a number of years very successfully they all felt that an expansion into a "Euro scheme" would be beneficial for the participants and also in terms of the expanded database.

Tab. 6 Comparison of results by method (major ones only) for each allergen.

\begin{tabular}{llllll}
\hline $\begin{array}{l}\text { Serum } \\
\text { pool }\end{array}$ & Allergen & Level & CAP & CAP & DPC \\
SP01 & D1 & Low & 4.0 & 0.5 & 7.8 \\
SP04 & D1 & Low & 1.8 & 1.6 & 1.1 \\
& D1 & Medium & 3.0 & 0.5 & 6.3 \\
& D1 & High & 2.3 & 1.1 & 2.0 \\
& Grass (G6) & & 1.7 & 1.1 & 1.6 \\
& Grass (G5) & & 2.2 & 1.8 & 1.2 \\
& Tree & Medium & 2.0 & 0.4 & 5.3 \\
& Tree & High & 3.0 & 1.0 & 3.1 \\
& E1 & High & 1.5 & 0.6 & 2.7 \\
& E1 & & 1.6 & 0.9 & 1.8 \\
& E5 & & 4.1 & 0.9 & 4.6 \\
& F1 & & 1.5 & 0.3 & 4.6 \\
& F3 & & 3.0 & 0.8 & 4.5 \\
& F13 & & 1.9 & 0.4 & 4.8 \\
M3 & & 3.0 & 0.6 & 5.1 \\
M6 & & 2.2 & 0.5 & 4.1 \\
\hline
\end{tabular}


Tab. 7 Analytical performance - by allergen mean running variance index scores.

\begin{tabular}{|c|c|c|c|c|c|c|}
\hline \multirow[t]{2}{*}{ Allergen } & \multirow[t]{2}{*}{ Country } & \multirow[t]{2}{*}{$\mathrm{n}$} & \multicolumn{4}{|c|}{ Mean running variance index score } \\
\hline & & & $<100$ & $100-200$ & $200-300$ & $>300$ \\
\hline D1 & $\begin{array}{l}\text { UK } \\
\text { Belgium } \\
\text { Netherlands }\end{array}$ & $\begin{array}{l}67 \\
82 \\
71\end{array}$ & $\begin{array}{l}13 \\
24 \\
28\end{array}$ & $\begin{array}{l}28 \\
29 \\
22\end{array}$ & $\begin{array}{r}20 \\
15 \\
16\end{array}$ & $\begin{array}{r}6 \\
14 \\
5\end{array}$ \\
\hline E1 & $\begin{array}{l}\text { UK } \\
\text { Belgium } \\
\text { Netherlands }\end{array}$ & $\begin{array}{l}66 \\
84 \\
67\end{array}$ & $\begin{array}{l}18 \\
33 \\
26\end{array}$ & $\begin{array}{l}30 \\
30 \\
23\end{array}$ & $\begin{array}{l}12 \\
11 \\
11\end{array}$ & $\begin{array}{r}6 \\
10 \\
7\end{array}$ \\
\hline $\mathrm{F} 1$ & $\begin{array}{l}\text { UK } \\
\text { Belgium } \\
\text { Netherlands }\end{array}$ & $\begin{array}{l}60 \\
66 \\
61\end{array}$ & $\begin{array}{l}18 \\
23 \\
29\end{array}$ & $\begin{array}{l}28 \\
22 \\
24\end{array}$ & $\begin{array}{r}11 \\
15 \\
7\end{array}$ & $\begin{array}{l}3 \\
6 \\
1\end{array}$ \\
\hline G5 & $\begin{array}{l}\text { UK } \\
\text { Belgium } \\
\text { Netherlands }\end{array}$ & $\begin{array}{l}26 \\
45 \\
34\end{array}$ & $\begin{array}{r}5 \\
5 \\
11\end{array}$ & $\begin{array}{l}10 \\
15 \\
10\end{array}$ & $\begin{array}{r}8 \\
15 \\
11\end{array}$ & $\begin{array}{r}3 \\
10 \\
2\end{array}$ \\
\hline M3 & $\begin{array}{l}\text { UK } \\
\text { Belgium } \\
\text { Netherlands }\end{array}$ & $\begin{array}{l}42 \\
54 \\
50\end{array}$ & $\begin{array}{l}5 \\
8 \\
9\end{array}$ & $\begin{array}{l}14 \\
18 \\
21\end{array}$ & $\begin{array}{l}12 \\
17 \\
13\end{array}$ & $\begin{array}{r}11 \\
11 \\
7\end{array}$ \\
\hline T3 & $\begin{array}{l}\text { UK } \\
\text { Belgium } \\
\text { Netherlands }\end{array}$ & $\begin{array}{l}41 \\
77 \\
51\end{array}$ & $\begin{array}{r}4 \\
12 \\
20\end{array}$ & $\begin{array}{l}18 \\
34 \\
18\end{array}$ & $\begin{array}{l}10 \\
19 \\
10\end{array}$ & $\begin{array}{r}9 \\
12 \\
3\end{array}$ \\
\hline E5 & $\begin{array}{l}\text { UK } \\
\text { Belgium } \\
\text { Netherlands }\end{array}$ & $\begin{array}{l}54 \\
78 \\
63\end{array}$ & $\begin{array}{l}14 \\
24 \\
22\end{array}$ & $\begin{array}{l}19 \\
27 \\
23\end{array}$ & $\begin{array}{l}14 \\
15 \\
10\end{array}$ & $\begin{array}{r}7 \\
12 \\
8\end{array}$ \\
\hline F13 & $\begin{array}{l}\text { UK } \\
\text { Belgium } \\
\text { Netherlands }\end{array}$ & $\begin{array}{l}45 \\
41 \\
44\end{array}$ & $\begin{array}{l}17 \\
17 \\
24\end{array}$ & $\begin{array}{l}15 \\
10 \\
10\end{array}$ & $\begin{array}{r}10 \\
10 \\
5\end{array}$ & $\begin{array}{l}3 \\
4 \\
5\end{array}$ \\
\hline M6 & $\begin{array}{l}\text { UK } \\
\text { Belgium } \\
\text { Netherlands }\end{array}$ & $\begin{array}{l}19 \\
51 \\
28\end{array}$ & $\begin{array}{r}3 \\
12 \\
7\end{array}$ & $\begin{array}{r}8 \\
20 \\
13\end{array}$ & $\begin{array}{r}5 \\
10 \\
2\end{array}$ & $\begin{array}{l}3 \\
9 \\
6\end{array}$ \\
\hline F3 & $\begin{array}{l}\text { UK } \\
\text { Belgium } \\
\text { Netherlands }\end{array}$ & $\begin{array}{l}46 \\
62 \\
29\end{array}$ & $\begin{array}{r}7 \\
15 \\
12\end{array}$ & $\begin{array}{l}15 \\
31 \\
12\end{array}$ & $\begin{array}{r}19 \\
10 \\
2\end{array}$ & $\begin{array}{l}5 \\
6 \\
3\end{array}$ \\
\hline
\end{tabular}

Tab. 8 Overall analytical performance - using overall mean running variance index score.

\begin{tabular}{|c|c|c|c|c|c|c|}
\hline \multirow[t]{2}{*}{ Country } & \multirow{2}{*}{$\begin{array}{l}\text { Distrib- } \\
\text { ution } \\
\text { no. }\end{array}$} & \multirow[t]{2}{*}{$\mathrm{n}$} & \multicolumn{4}{|c|}{ Overall mean running variance index score } \\
\hline & & & $<100$ & $100-200$ & $200-300$ & $>300$ \\
\hline UK & $\begin{array}{r}9 \\
13\end{array}$ & $\begin{array}{l}51 \\
59\end{array}$ & $\begin{array}{l}7 \\
6\end{array}$ & $\begin{array}{l}32 \\
33\end{array}$ & $\begin{array}{l}11 \\
16\end{array}$ & $\begin{array}{l}1 \\
4\end{array}$ \\
\hline Belgium & $\begin{array}{r}9 \\
13\end{array}$ & $\begin{array}{l}76 \\
68\end{array}$ & $\begin{array}{l}15 \\
12\end{array}$ & $\begin{array}{l}39 \\
35\end{array}$ & $\begin{array}{l}20 \\
13\end{array}$ & $\begin{array}{l}2 \\
8\end{array}$ \\
\hline Netherlands & $\begin{array}{r}9 \\
13\end{array}$ & $\begin{array}{l}55 \\
58\end{array}$ & $\begin{array}{l}21 \\
17\end{array}$ & $\begin{array}{l}23 \\
30\end{array}$ & $\begin{array}{r}11 \\
9\end{array}$ & $\begin{array}{l}0 \\
2\end{array}$ \\
\hline Total & $\begin{array}{r}9 \\
13\end{array}$ & $\begin{array}{l}182 \\
185\end{array}$ & $\begin{array}{l}43 \\
35\end{array}$ & $\begin{array}{l}94 \\
98\end{array}$ & $\begin{array}{l}42 \\
38\end{array}$ & $\begin{array}{r}3 \\
14\end{array}$ \\
\hline
\end{tabular}

Hence 1992 saw the launch of a joint co-operation scheme with common serum pools, common distribution and reporting dates and a common Euro report. This was * made possible by maintaining the national identity and organisation of each scheme and also excellent co-oper- ation in the organisation and administration by the three national organisers.

The choice of specific IgE antibodies to test against was restricted in the first instance to the 8-10 most common allergens occurring in Western Europe and the choice 
was borne out by the good analysis frequency of almost all the allergens in circulation; the exception being the mould Alternaria (M6) which was analysed by much fewer of the participants than M3 or the other allergens.

The scheme as a whole has been enthusiastically received (even as a subscription-based scheme) and has shown an increase in membership from 1992 to the beginning of 1993 for all three countries. We are currently exploring the possibility of inviting further countries in Western Europe to participate - the advantage of this scheme over others is that it is open to all types of laboratories regardless of the method of analysis they use.

One of the advantages of a Euro scheme over a national one was thought to be the greater database of lesser known methods but we found a movement towards greater use of the Pharmacia CAP method during the year and thus the number of participants using some of the other commercial methods is still very small (i.e. $<5$ or 6 users). Specific IgE analysis is in reality a multi-analyte system where the antibodies to each different allergen should be considered as separate analytes despite some common features such as solid phase and 2nd antibody and because of this the EQA scheme is far more complex than that of other analytes and schemes. Thus analysis of overall results should be treated with great caution.

The purification of allergens and preparation of protein extracts can vary between different commercial suppliers and then the types of solid phases for the binding of these extracts are also very varied between manufacturers. These variations coupled with differences in antibody production and lack of international reference material makes the assay of specific IgE antibodies very complex and thus the use of EQA results in defining assay performance is just as complex.

Because of these problems the first major criteria in data analysis and performance criteria was to decide to use method related mean results as the designated values for variance index score calculations. Thus all laboratories would be compared to the designated values for their method for all allergens being tested and therefore a performance criteria could be set for each method group.

Comparisons between methods should be treated with caution as they would depend on whether an allergen was "recognised" as positive or negative similarly by all methods. Sadly for the time being this scheme is really unable to directly compare results in any way between manufacturers and' even between different methods from the same manufacturer. This problem is aptly shown by comparing the responses to "house dust mite" by the Pharmacia CAP and DPC Alastat methods in serum pools SP01 and SP04. The usefulness in examining results by grades or classes and units is leading to the belief that clinical performance criteria could be established using a consensus result in grades and results in units whilst not comparable between methods could be used to calculate mean running variance index score and overall mean running variance index score which are a measure of analytical performance.

\section{Conclusions and Future}

1) Interest in an external quality assessment scheme organised on a multi-national basis is gaining with increases in membership within each of the three participating countries.

2) There is a need to enlarge our result database by country and by method (especially methods with currently small numbers of users).

3) The range of allergens used for testing is still to be restricted to the 8-10 most commonly requested allergens in Western Europe.

4) It was also considered useful to test against $2-3$ of the most common allergens at more than one antibody concentration.

5) It appears a useful experiment to add recovery experiments to allergens such as D1, E1 or T3 using a serum pool diluted to 3 or 4 antibody concentration levels.

6) We will continue to use as the designated value for any result the method related trimmed mean because of the great variation in results between methods.

7) Progress will be made in separating criteria of performance into clinical and analytical whereby clinical performance by judged by the results in grades and analytical performance by the results in units.

8) Mean running variance index score and overall mean running variance index score will continue to be used to compare the performance of laboratories analytical results in units.

9) It may be necessary to install different chosen coefficient of variation for each allergen depending on the quality and variation of results between allergens.

10). Changes in the data handling of results to grass and tree pollens may be necessary to separate results to mixed and single allergens.

11) It is hoped that by speedier transference of data it will be possible to issue regular reports to participants quicker than at present.

12) Attempts to help improve standardisation and harmonisation of specific IgE assays will be continued. 


\section{References}

1. Ishizaka, K. \& Ishizaka, T. (1967) Physicochemical properties of reaginic antibody. I. Association of reaginic activity with an immunoglobulin other than gamma $A$ or gamma $G$ globulin. J. Allergy 37, 169-185.

2. Johansson, S. G. O. (1967) Raised levels of a new immunoglobulin class (IgND) in asthma. Lancet 2, 951-953.

3. Wide, L., Bennich, H. \& Johansson, S. G. O. (1967) Diagnosis of allergy by an in vitro test for allergen antibodies. Lancet 2 , 1105-1107.

4. Hamilton, R. G. \& Adkinson, N. F. Jr. (1986) Clinical laboratory methods for the assessment and management of human allergic diseases. Clin. Lab. Med. 6, 117-138.

5. Hamilton, R. G. \& Atkinson, N. F. Jr. (1992) Measurement of total serum immunoglobulin $E$ and allergen-specific immuno- globulin E antibody. In: Manual of Clinical Laboratory Immunology (Rose, N. R., De Macañio, E. C., Fahey, J. L., Friedman, H. \& Penn, G. M, eds.) 4th edition, Washington, D. C. American Society for Microbiology, pp. 689-701.

6. Bullock, D. G. \& Wilde, C. E. (1985) External quality assessment of urinary pregnancy oestrogen assay: Further experience in the United Kingdom. Ann. Clin. Biochem. 22, 273-282.

Dr R. Fifield

Supra Regional Protein Reference Unit Cardiff Royal Infirmary

Cardiff CF2 1SZ

Wales, UK 